\title{
Short-term changes in a microplankton community in the Chukchi Sea during autumn: consequences of a strong wind event
}

\author{
Naoya Yokoi ${ }^{1}$, Kohei Matsuno ${ }^{2}$, Mutsuo Ichinomiya ${ }^{3}$, Atsushi Yamaguchi ${ }^{1}$, Shigeto Nishino ${ }^{4}$, Jonaotaro Onodera ${ }^{4}$, \\ Jun Inoue $^{3}$, and Takashi Kikuchi ${ }^{4}$ \\ ${ }^{1}$ Laboratory of Marine Biology, Graduate School of Fisheries Sciences, Hokkaido University, 3-1-1 Minato-cho, \\ Hakodate, Hokkaido 041-8611, Japan \\ ${ }^{2}$ Arctic Environment Research Center, National Institute of Polar Research, 10-3 Midori-cho, \\ Tachikawa, Tokyo 190-8518, Japan \\ ${ }^{3}$ Prefectural University of Kumamoto, Tsukide 3-1-100, Higashi, Kumamoto 862-8502, Japan \\ ${ }^{4}$ Japan Agency for Marine-Earth Science and Technology, 2-15 Natsushima-cho, Yokosuka, Kanagawa 237-0061, Japan \\ Correspondence to: Naoya Yokoi (n-yokoi@fish.hokudai.ac.jp)
}

Received: 23 February 2015 - Published in Biogeosciences Discuss.: 15 June 2015

Revised: 6 January 2016 - Accepted: 4 February 2016 - Published: 18 February 2016

\begin{abstract}
Recent studies indicate an increase in atmospheric turbulence in the Chukchi Sea due to the recent drastic sea-ice reduction during summer months. The importance of the effects of this atmospheric turbulence on the marine ecosystem in this region, however, is not fully understood. To evaluate the effects of atmospheric turbulence on the marine ecosystem, high-frequency sampling (daily) from five layers of the microplankton community between 0 and $30 \mathrm{~m}$ at a fixed station in the Chukchi Sea from 10 through 25 September 2013 was conducted. During the study period, a strong wind event (SWE) was observed on 18 and 19 September. The abundance of microplankton was 2.6 to 17.6 cells $\mathrm{mL}^{-1}$, with a maximum abundance being reported at $20 \mathrm{~m}$ on 22 September, while diatoms were the most dominant taxa throughout the study period. The abundance of diatoms, dinoflagellates and ciliates ranged between 1.6 and $14.1,0.5$ and 2.4 and 0.1 and 2.8 cells $\mathrm{mL}^{-1}$, respectively. Diatoms belonging to 7 genera consisting of 35 species (Cylindrotheca closterium and Leptocylindrus danicus were dominant), dinoflagellates belonging to 7 genera consisting of 25 species (Prorocentrum balticum and Gymnodinium spp. were dominant) and ciliates belonging to 7 genera consisting of 8 species (Strobilidium spp. and Strombidium spp. were dominant) were identified. Within the microplankton species, there were 11 species with abundances that increased after the SWE, while there was no species with an abundance that decreased following the SWE. It is conjectured that at-
\end{abstract}

mospheric turbulences, such as that of an SWE, may supply sufficient nutrients to the surface layer that subsequently enhance the small bloom under the weak stratification of the Chukchi Sea Shelf during the autumn months. After the bloom, the dominant diatom community then shifts from centric-dominated to one where centric/pennate are more equal in abundance.

\section{Introduction}

In the marine ecosystem of the western Arctic Ocean, microplankton, including diatoms, dinoflagellates and ciliates, play several roles, such as primary producers, consumers and food resources for mesozooplankton (Sherr and Sherr, 1988, Sherr et al., 1997; Olson and Strom, 2002). The microplankton community in the western Arctic Ocean is divided into three groups - shelf, continental slope and basin (Sukhanova et al., 2009; Matsuno et al., 2014). As a special characteristic, during the summer, the development of pycnocline prevents the supply of nutrients to the surface layer, and phytoplankton (as determined by chlorophyll $a$ ) form a maximum subsurface layer that may be between 20 and $30 \mathrm{~m}$ in depth (Hill and Cota, 2005; Sukhanova et al., 2009; Joo et al., 2012). With respect to the microplankton community on the shelf of the Chukchi Sea, diatoms are the dominant taxa both in abundance and biomass (Matsuno et 
al., 2014; Yang et al., 2015). Regarding temporal changes in the microplankton community, seasonal comparisons with 3- to 4-month sampling intervals (Sukhanova et al., 2009) and year-round changes with 8-day intervals were reported (Sherr et al., 2003). As microplankton grow rapidly (Strom and Fredrickson, 2008; Sherr et al., 2009), fine temporal resolution (every day) is required to evaluate detailed temporal changes in their community. However, such high-frequency sampling of microplankton has not been conducted previously.

In recent years, a drastic decrease in sea ice has been reported for the western Arctic Ocean during the summer months, and even greater related changes in sea surface temperatures have been reported (Stroeve et al., 2007; Steele et al., 2008). The changes in sea surface temperatures, increases in the frequency and intensity of cyclones, and northward shifts from their tracks during the summer months as well as during other seasons have also been reported (Serreze et al., 2000; McCabe et al., 2001; Sepp and Jaagus, 2011). While these changes are important, little is known about the effects of atmospheric and oceanic changes on the marine ecosystem in the western Arctic Ocean. During the period from 10 to 25 September 2013, high-frequency (daily) sampling and observations were conducted at a fixed station in the western Arctic Ocean, and the occurrence of strong wind events (SWEs), vertical flux of nutrients and changes in primary production were reported (Nishino et al., 2015). However, it is not clear how the microplankton assemblages - diatoms, dinoflagellates, ciliates - respond to the SWEs and the changes in nutrient supply and primary production.

In the present study, we evaluate short-term changes in the microplankton community in the Chukchi Sea during the autumn months by quantification of both autotrophic and heterotrophic microplankton assemblages - diatoms, dinoflagellates, ciliates - based on the samples collected during the same time frame as Nishino et al. (2015). Note that we only observed microplankton and did not quantify nano- and pico-plankton in this paper. We conducted a cluster analysis based on microplankton abundance and evaluated the effect of SWEs on microplankton assemblages under weak stratification in the Chukchi Sea due to atmospheric cooling during the autumn months.

\section{Materials and methods}

\subsection{Field sampling}

Water samples were collected from a fixed station in the Chukchi Sea $\left(72^{\circ} 45^{\prime} \mathrm{N}, 168^{\circ} 15^{\prime} \mathrm{W}\right.$; depth $\left.56 \mathrm{~m}\right)$ between 10 and 25 September 2013 (Fig. 1). At approximately 09:30 (local time) every day, $12 \mathrm{~L}$ of seawater was collected from depths of $0,5,10,20$ and $30 \mathrm{~m}$ using a rosette multi-sampler mounted on a CTD (Sea-Bird Electronics). A total of 80 samples were collected ( 16 days $\times 5$ depths). Temperature and salinity were measured using CTD, and $1 \mathrm{~L}$ water samples

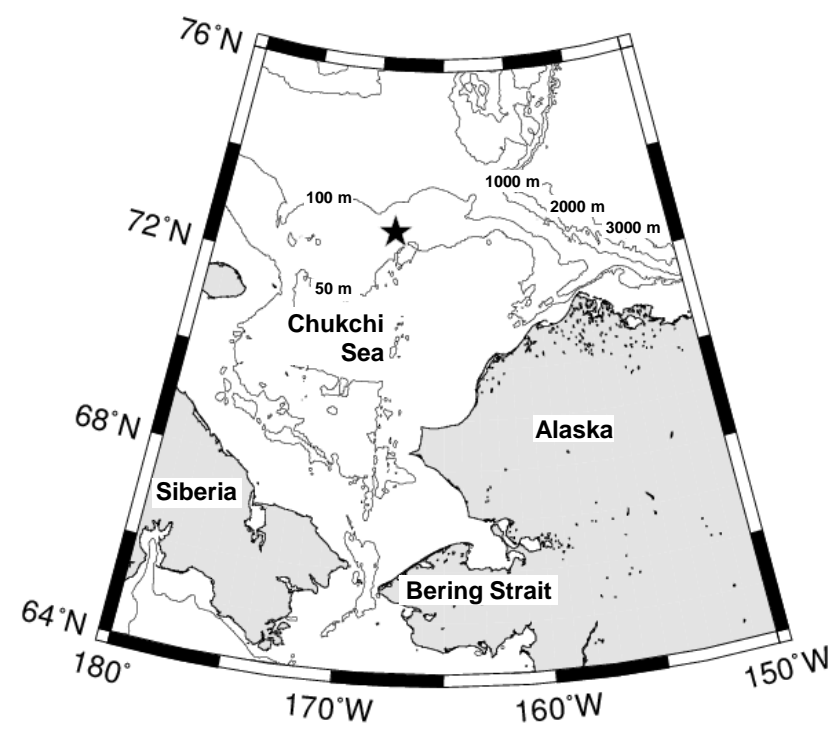

Figure 1. Location of the sampling station in the Chukchi Sea. Depth contours at 50, 100 and $1000 \mathrm{~m}$ are superimposed.

were preserved with $1 \%$ glutaraldehyde and stored in a dark cold room. Nutrients (nitrate, nitrite, ammonium and silicic acid) were measured on $10 \mathrm{~mL}$ water samples using an autoanalyser (Bran + Luebbe GmbH, TRAACS-800). For each sample, duplicate $1 \mathrm{~L}$ seawater samples were filtered through a GF/F filter, and chlorophyll $a(\operatorname{chl} a)$ was measured with a fluorometer (Turner Design, Inc., 10-AU-005).

\subsection{Microplankton analysis}

In a land laboratory, $1 \mathrm{~L}$ preserved samples were concentrated to $18 \mathrm{~mL}$ with the settlement of microplankton cells at the bottom of the bottle, and a syphon was used to drain the clear water from the top. To obtain cell counts of diatoms and ciliates, subsamples $(0.1$ to $0.2 \mathrm{~mL})$ were mounted on a glass slide and counted under an inverted microscope. For species identification, we referenced Hasle and Syvertsen (1997) and Hoppenrath et al. (2009) for diatoms and Maeda (1997) and Taniguchi (1997) for ciliates. To distinguish thecate and athecate forms for cell counts of dinoflagellates, after staining subsamples with calcofluor $\left(1 \mathrm{mg} \mathrm{ml}^{-1}\right)$ for more than $1 \mathrm{~h}$, subsamples $(0.1$ to $0.2 \mathrm{~mL})$ were mounted on a glass slide and counted under an epifluorescence microscope with UV light excitation (Fritz and Triemer, 1985). For species identification of dinoflagellates, we referenced Fukuyo et al. (1997) and Hoppenrath et al. (2009). From each sample, we counted and identified cells that were larger than $10 \mu \mathrm{m}$. Because we did not check pigments in the cell, the nutrition of dinoflagellates (heterotrophs, autotrophs and mixotrophs) was not distinguishable in this study. 


\subsection{Statistical analysis}

For cluster analysis, the abundance $\left(X\right.$ : cells $\left.\mathrm{L}^{-1}\right)$ of diatoms was $\log$-transformed $\left(\log _{10}[X+1]\right)$ prior to the analysis to reduce any bias in abundances (Field et al., 1982). Similarities between samples were examined using the Bray-Curtis method (Bray and Curtis, 1957). To group the samples, similarity indices were coupled with hierarchical agglomerative clustering using a complete linkage method - the unweighted pair group method - using the arithmetic mean, UPGMA (Field et al., 1982). All analyses were performed using PRIMER v6 (PRIMER-E Ltd.). We evaluated differences in abundances of each species between groups using a one-way ANOVA and post hoc Tukey-Kramer tests. During the study period, a SWE was observed on approximately 19 to 22 September (Kawaguchi et al., 2015; Nishino et al., 2015). According to Kawaguchi et al. (2015), there were meteorologically and oceanographically distinct periods between 10 and 18 September and 19 and 26 September, represented as terms I and II, respectively. Term II was characterized by longer, stronger northeasterly winds, which continued for several days between 19 and 22 September, the average intensity of which was greater than $13 \mathrm{~m} \mathrm{~s}^{-1}$. To evaluate the effect of the SWE, the abundances of each microplankton taxon and species were compared "before the SWE (1018 September)" and "after the SWE (19-25 September)" using the $U$ test. This statistical analysis was performed using StatView.

\section{Results}

\subsection{Hydrography}

Through the sampling period, temperatures ranged from -1.5 to $3.3^{\circ} \mathrm{C}$ (Fig. 2a). Cold water below $0{ }^{\circ} \mathrm{C}$ was observed at depths below $20 \mathrm{~m}$, and thermocline occurred at approximately $25 \mathrm{~m}$. The temperatures in the upper thermocline decreased from 3 to $1.5^{\circ} \mathrm{C}$ during the study period. Salinity ranged from 31.0 to 32.7 , and high-salinity water (>32) was observed at depths below $20 \mathrm{~m}$. Halocline was observed at approximately $25 \mathrm{~m}$, which paralleled that of the thermocline. Salinity in the upper halocline increased from 31.1 at the start of the sampling period (10 September) to 31.6 at the end of the sampling period (25 September) (Fig. 2b). From Sigma- $T$, the development of pycnocline was observed at approximately 20 to $30 \mathrm{~m}$ during the study period (Fig. 2c). DIN (dissolved inorganic nitrogen: $\mathrm{NO}_{3}+\mathrm{NO}_{2}+\mathrm{NH}_{4}^{+}$) concentration ranged from 0.02 to $18.1 \mu \mathrm{M}$, while the nutricline was observed at approximately 30 to $40 \mathrm{~m}$ (Fig. 2d). Silicates ranged from 0.5 to $32.3 \mu \mathrm{M}$, and their nutricline was observed at approximately 40 to $50 \mathrm{~m}$. Compared with DIN, silicate concentration was relatively higher ( $>2 \mu \mathrm{M}$ even at the surface layer) (Fig. 2e). Chl $a$ ranged from 0.1 to $3.2 \mu \mathrm{g} \mathrm{L}-1$, and relatively high chl $a$ was observed at depths less than $30 \mathrm{~m}$ (Fig. 2f). After the (a) Temp. $\left({ }^{\circ} \mathrm{C}\right)$

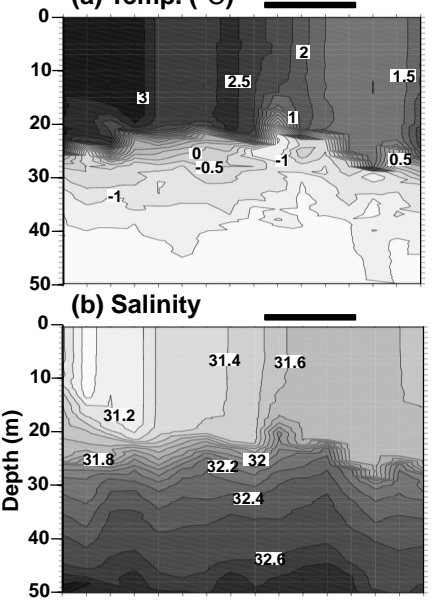

(c) Sigma-T

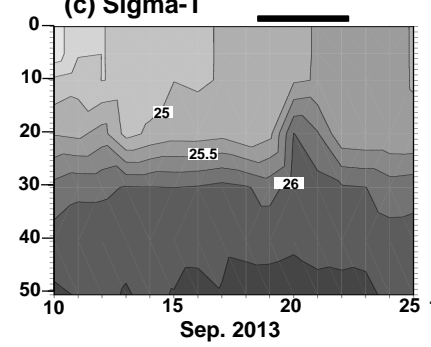

(d) DIN $(\mu \mathrm{M})$

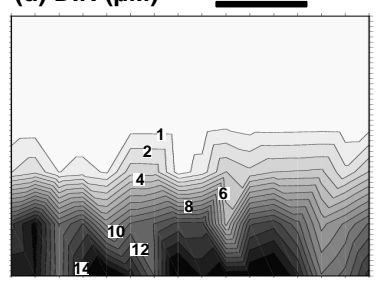

(e) Silicate $(\mu \mathrm{M})$

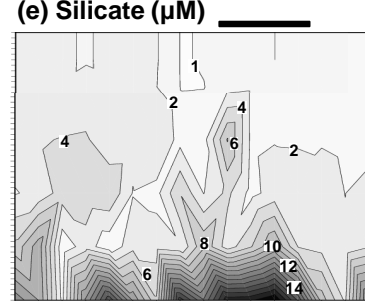

(f) $\mathrm{Chl} \mathrm{a} \mathrm{( \mu g} \mathrm{\textrm {L } ^ { - 1 } )}$

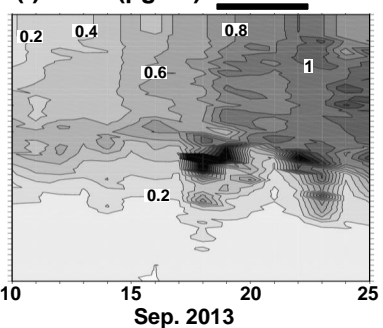

Figure 2. Temporal and vertical changes in temperature $\left({ }^{\circ} \mathrm{C}\right)(\mathbf{a})$, salinity (b), sigma- $T$ (c), dissolved inorganic nitrogen $(\mu \mathrm{M})(\mathbf{d})$, silicate $(\mu \mathrm{M})(\mathbf{e})$ and chlorophyll $a\left(\mu \mathrm{L} \mathrm{L}^{-1}\right)$ (f) at a fixed station in the Chukchi Sea between 10 and 25 September 2013. Solid bars indicate the timing of the strong wind event.

SWE, chl $a$ increased in the upper $30 \mathrm{~m}$ and remained high until the end of the study period. It is notable that the sporadic high chl $a$ was observed at approximately $25 \mathrm{~m}$ on 18 , 19 and 22 September - the days following the SWE.

\subsection{Microplankton assemblage}

In the present study, diatoms belonging to 7 genera and 35 species, dinoflagellates belonging to 7 genera and 25 species, and ciliates belonging to 7 genera and 8 species were identified (Table 1). Within the microplankton species, 11 species increased in abundance after the SWE, while no species decreased in abundance after the SWE (Table 1).

\subsection{Diatoms}

The mean abundance of diatoms ( 0 to $30 \mathrm{~m}$ ) ranged from 1.6 to 14.1 cells $\mathrm{mL}^{-1}$. The dominant species for centric diatoms was Leptocylindrus danicus, while the dominant species for pennate diatoms was Cylindrotheca closterium (Fig. 3a). Centric diatoms showed a maximum abundance on 16 September (before the SWE) (Fig. 3b), while pennate diatoms increased in abundance throughout the water column after 20 September (after the SWE) (Fig. 3c). With 
(a) Species composition

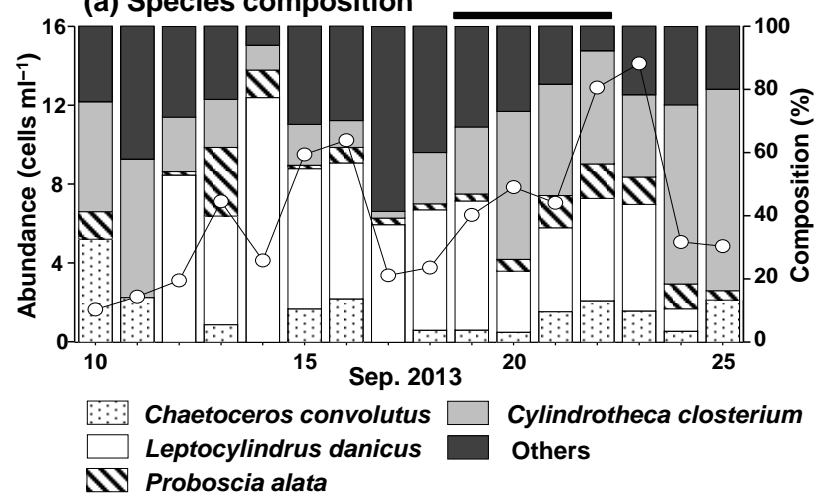

(b) Centric diatoms (cells $\mathrm{ml}^{-1}$ )

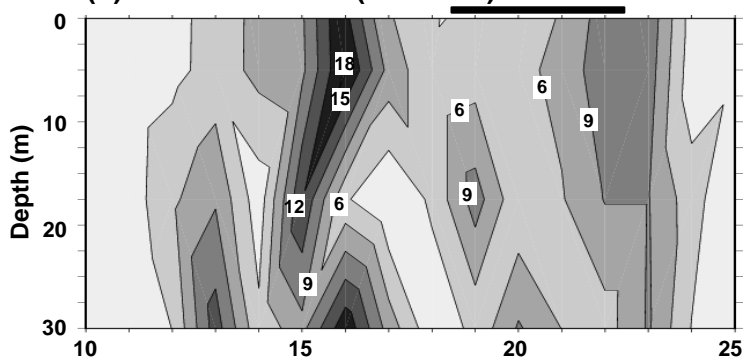

(c) Pennate diatoms (cells $\mathrm{ml}^{-1}$ )

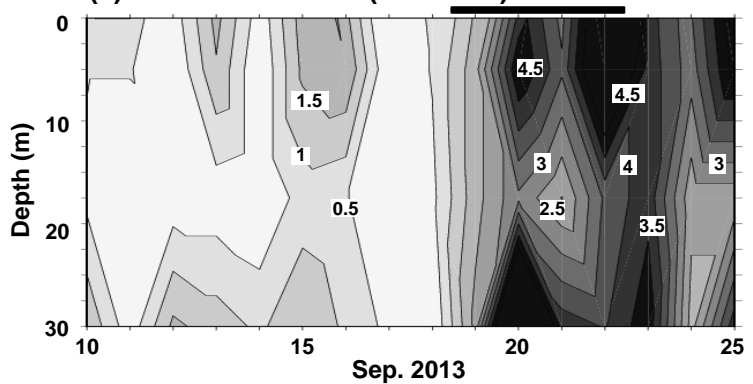

Figure 3. Temporal changes in cell density and species composition of total diatoms (a), the vertical distribution of centric diatoms (cells $\mathrm{mL}^{-1}$ ) (b) and pennate diatoms (cells $\mathrm{mL}^{-1}$ ) (c) in the Chukchi Sea during the period from 10 to 25 September 2013. In (a), values represent the mean of diatom abundance between 0 and $30 \mathrm{~m}$. Solid bars indicate the timing of a strong wind event.

respect to the diatoms, five species increased in abundance after the SWE - Chaetoceros furcellatus (resting spore), Dactyliosolen fragilissimus and Rhizosolenia spp. for centric diatoms, and Cylindrotheca closterium and Navicula spp. for pennate diatoms (Table 1).

\subsection{Dinoflagellates}

The mean abundance of dinoflagellates $(0$ to $30 \mathrm{~m})$ ranged from 0.5 to 2.4 cells $\mathrm{mL}^{-1}$. The dominant species of thecate dinoflagellates was Prorocentrum balticum and Gymnodinium spp. for athecate dinoflagellates (Fig. 4a). Temporal changes in vertical distribution were similar for thecate and athecate dinoflagellates, with both exhibiting high abundance at $20 \mathrm{~m}$ on 15 September and at $5 \mathrm{~m}$ on 19 September (a) Species composition

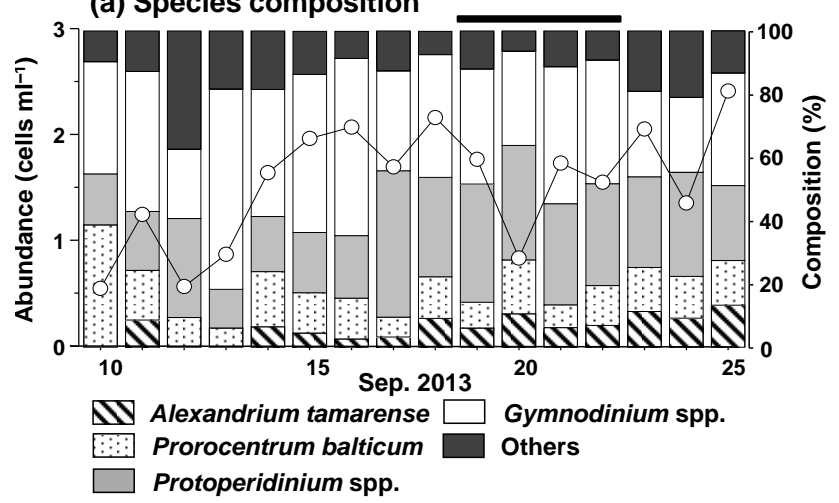

(b) Thecate dinoflagellates (cells $\mathrm{m}^{-1}$ )

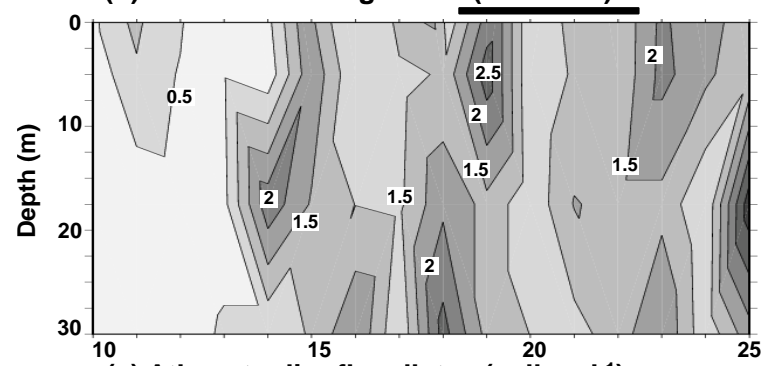

(c) Athecate dinoflagellates (cells $\mathrm{ml}^{-1}$ )

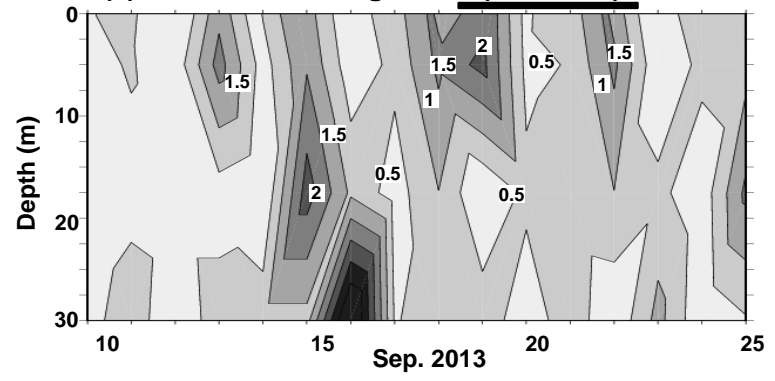

Figure 4. Temporal changes in cell density and species composition of total dinoflagellates (a), vertical distribution of thecate dinoflagellates (cells $\mathrm{mL}^{-1}$ ) (b) and athecate dinoflagellates (cells $\mathrm{mL}^{-1}$ ) (c) in the Chukchi Sea for the period from 10 to 25 September 2013. In (a), values represent the mean of dinoflagellate abundance between 0 and $30 \mathrm{~m}$. Solid bars indicate the timing of a strong wind event.

(Fig. 4b, c). Five thecate dinoflagellate species increased in abundance after the SWE - Alexandrium tamarense, Oxytoxum sp. 2, Protoperidinium bipes, P. conicum and P. pellucidum (Table 1).

\subsection{Ciliates}

Mean abundance of ciliates ( 0 to $30 \mathrm{~m}$ ) ranged from 0.1 to 2.8 cells $\mathrm{mL}^{-1}$. The dominant species were the oligotrich ciliates Strobilidium spp. and Strombidium spp. (Fig. 5a). Temporal changes in vertical distribution varied between oligotrich and tintinnid ciliates. For oligotrich ciliates, high abundances were observed at 4-day intervals until 20 September (Fig. 5b). For tintinnid ciliates, high abundance was noted af- 
Table 1. List of microplankton species and their mean cell densities (cells $\mathrm{L}^{-1}$ ) at a single station in the Chukchi Sea between 10 and 18 September (before SWE) and 19 and 25 September (after SWE) 2013. NS: not significant; *: $p<0.05 ; * *: p<0.01 ; * * *: p<0.001$.

\begin{tabular}{|c|c|c|c|}
\hline Species & $\begin{array}{r}\text { Before SWE } \\
(10-18 \text { September) }\end{array}$ & $\begin{array}{r}\text { After SWE } \\
\text { (19-25 September) }\end{array}$ & $U$ test \\
\hline \multicolumn{4}{|l|}{ Centric diatoms } \\
\hline Chaetoceros affinis & 308 & 113 & NS \\
\hline Chaetoceros borealis & 28 & 67 & NS \\
\hline Chaetoceros compressus & 224 & 273 & NS \\
\hline Chaetoceros convolutus & 120 & 237 & NS \\
\hline Chaetoceros concavicornis & 424 & 730 & NS \\
\hline Chaetoceros decipience & 52 & 77 & NS \\
\hline Chaetoceros furcellatus (resting spore) & 12 & 252 & $* *$ \\
\hline Chaetoceros laciniosus & 28 & 113 & NS \\
\hline Chaetoceros sp. & 48 & 108 & NS \\
\hline Dactyliosolen fragilissimus & & 139 & $*$ \\
\hline Leptocylindrus danicus & 2068 & 2186 & NS \\
\hline Leptocylindrus danicus (resting spore) & 84 & 5 & NS \\
\hline Leptocylindrus minimus & 424 & 129 & NS \\
\hline Proboscia alata & 316 & 617 & NS \\
\hline Rhizosolenia borealis & 20 & 15 & NS \\
\hline Rhizosolenia setigera & 172 & 118 & NS \\
\hline Rhizosolenia spp. & & 21 & $*$ \\
\hline \multicolumn{4}{|l|}{ Pennate diatoms } \\
\hline Cylindrotheca closterium & 700 & 3111 & $* * *$ \\
\hline Navicula spp. & & 15 & $*$ \\
\hline \multicolumn{4}{|l|}{ Thecate dinoflagellates } \\
\hline Alexandrium tamarense & 68 & 157 & * \\
\hline Ceratium horridum & & 3 & NS \\
\hline Gonyaulax scrippsae & 2 & 8 & NS \\
\hline Gonyaulax spp. & 6 & 3 & NS \\
\hline Oxytoxum sp.1 & 98 & 72 & NS \\
\hline Oxytoxum sp. 2 & 2 & 15 & $*$ \\
\hline Prorocentrum balticum & 192 & 203 & NS \\
\hline Prorocentrum compressum & & 5 & NS \\
\hline Prorocentrum minimum & 16 & 36 & NS \\
\hline Protoceratium reticulatum & 40 & 26 & NS \\
\hline Protoperidinium avellanum & 68 & 95 & NS \\
\hline Protoperidinium bipes & 56 & 177 & $* *$ \\
\hline Protoperidinium conicum & & 10 & $* *$ \\
\hline Protoperidinium leonis & & 3 & NS \\
\hline Protoperidinium marukawai & 12 & 10 & NS \\
\hline Protoperidinium mite & & 3 & NS \\
\hline Protoperidinium monovelum & 34 & 28 & NS \\
\hline Protoperidinium pellucidum & & 21 & $* *$ \\
\hline Protoperidinium punctulatum & 96 & 90 & NS \\
\hline Protoperidinium subinerme & 4 & 3 & NS \\
\hline Protoperidinium thorianum & 76 & 80 & NS \\
\hline Protoperidinium sp. 1 & 4 & 0 & NS \\
\hline Protoperidinium spp. & 2 & 3 & NS \\
\hline Scripsiella crystallina & 28 & 64 & NS \\
\hline \multicolumn{4}{|l|}{ Athecate dinoflagellates } \\
\hline Gymnodinium spp. & 628 & 573 & NS \\
\hline \multicolumn{4}{|l|}{ Oligotrich ciliates } \\
\hline Lohmanniella spp. & 16 & 21 & NS \\
\hline Strobilidium spp. & 408 & 638 & NS \\
\hline Strombidium strobilum & 56 & 26 & NS \\
\hline Strombidium spp. & 720 & 962 & NS \\
\hline Tontonia gracillima & 72 & 67 & NS \\
\hline \multicolumn{4}{|l|}{ Tintinnid ciliates } \\
\hline Parafavella denticulata & 4 & 0 & NS \\
\hline Ptychocylis obtusa & 12 & 57 & $*$ \\
\hline Tintinnopsis sp. & 8 & 0 & NS \\
\hline
\end{tabular}


(a) Species composition

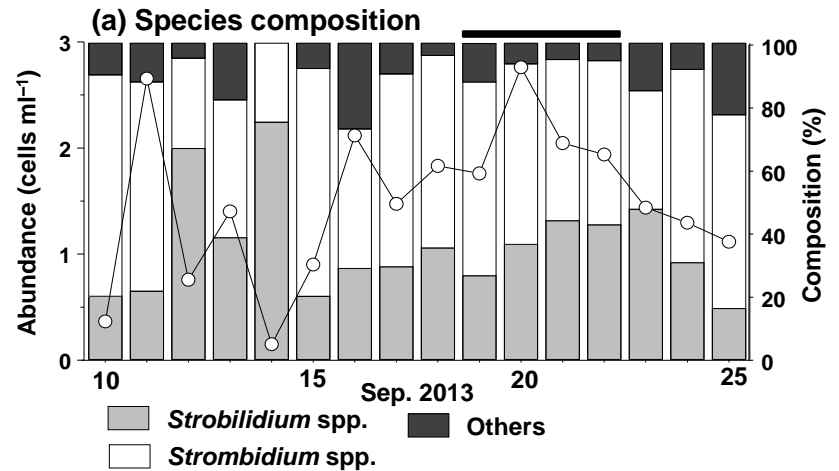

(b) Oligotrich ciliates (cells $\mathrm{ml}^{-1}$ )

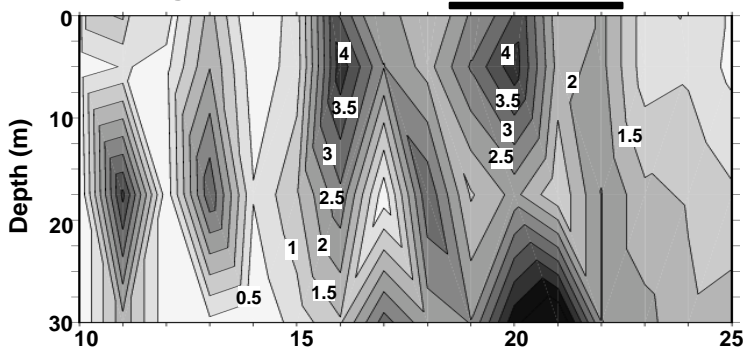

(c) Tintinnid ciliates (cells $\mathrm{ml}^{-1}$ )

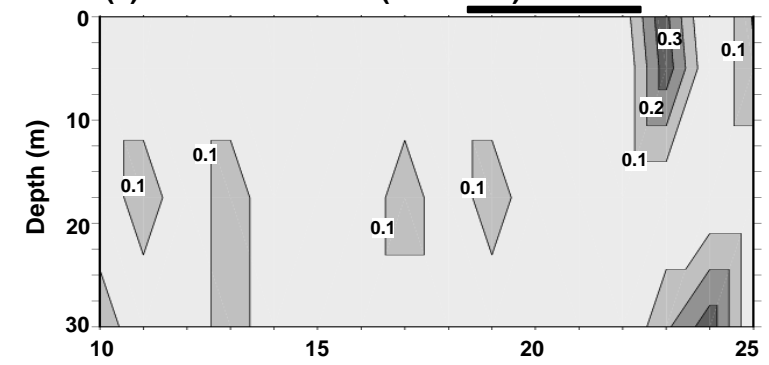

Figure 5. Temporal changes in cell density and species composition of total ciliates (a), the vertical distribution of oligotrich ciliates $\left(\right.$ cells $\left.\mathrm{mL}^{-1}\right)(\mathbf{b})$ and tintinnid ciliates (cells $\mathrm{mL}^{-1}$ ) (c) in the Chukchi Sea during the period from 10 to 25 September 2013. In (a), values represent the mean ciliate abundance between 0 and $30 \mathrm{~m}$. Solid bars indicate the timing of a strong wind event.

ter 22 September (Fig. 5c). Only one ciliate species (tintinnid Ptychocylis obtusa) increased in abundance after the SWE (Table 1).

\subsection{Temporal and spatial changes in community structure}

As a feature of microplankton assemblages in this study, diatoms were the dominant taxa (comprising $68.0 \%$ of mean abundance). For dinoflagellates, the proportion of the autotrophic species (such as P. balticum and A.tamarense) was low, while that of the heterotrophic species (such as Protoperidinium spp. and Gymnodinium spp.) was high (Table 1). With this in mind, we conducted a cluster analysis based on the abundance of diatoms. For other taxa (dinoflag- (a)

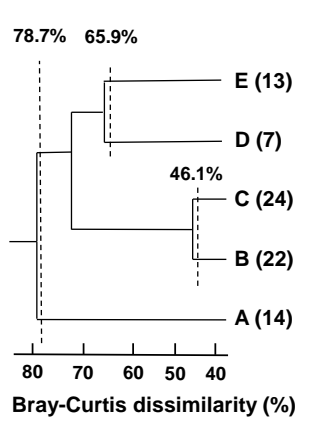

(b)

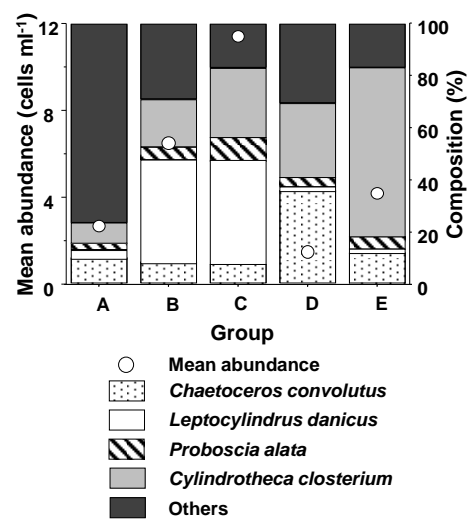

(c)

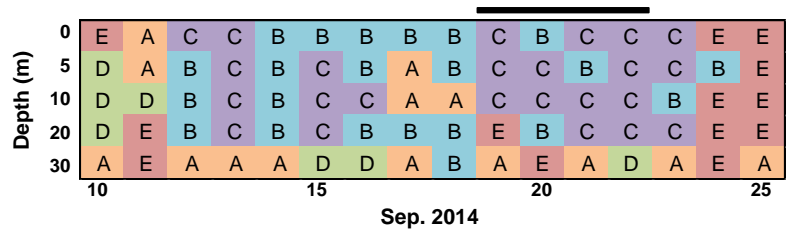

Figure 6. (a) Results of cluster analysis based on diatom cell density in the Chukchi Sea from 10 to 25 September 2013. Five groups (A to E) were identified at 46 to $78 \%$ Bray-Curtis dissimilarity connected using UPGMA. Numbers in parentheses indicate the number of samples in each group. (b) Mean abundance and species composition of each group. (c) Vertical and temporal distribution of each group. Solid bar in (C) indicates the timing of a strong wind event.

ellates and ciliates), their communities were evaluated based on the relationship with communities of diatoms.

A cluster analysis based on diatom abundance classified their community into five groups (A to E) at 46.1, 65.9 and $78.7 \%$ dissimilarity levels (Fig. 6a). Each group contained between 7 and 24 samples. The highest abundance was observed for group C, followed by groups B, E, A and D. Group A exhibited no distinct dominant species, while groups B and $\mathrm{C}$ were dominated by $L$. danicus and C. closterium, and group E was dominated by C. closterium (Fig. 6b).

Comparisons between and among groups indicated that there were eight species with significantly different numbers from one group to another according to a one-way ANOVA, $p<0.05$, as presented in Table 2. Compared to the other groups, group A had a higher abundance of the centric diatom Chaetoceros sp.; group B had a higher abundance of the thecate dinoflagellate Protoceratium reticulatum; group $\mathrm{C}$ had a higher abundance of the centric diatom $L$. danicus, L. minimus and P. alata, the pennate diatom C. closterium, and the thecate dinoflagellate $P$. bipes; and group $\mathrm{E}$ had a higher abundance of the tintinnid ciliate $P$. obtusa (Table 2). No species were found to dominate group D.

With respect to temporal and vertical distribution of each group, group D dominated the water column on 10 September (Fig. 6c). From 12 to 18 September, group B dominated at the 0 to $20 \mathrm{~m}$ level in the water column, while other groups 
Table 2. Mean cell densities (cells $\mathrm{L}^{-1}$ ) of microplankton in each group identified by cluster analysis (cf. Fig. 6) in the Chukchi Sea between 10 and 25 September 2013. Numbers in parentheses indicate the number of samples included. Differences between groups were tested by one-way ANOVA and the Tukey-Kramer test. Any groups not connected by the underlines are significantly different $(p<0.05)$. NS: not significant; *: $p<0.05 ; * *: p<0.01 ; * * *: p<0.001$.

\begin{tabular}{|c|c|c|c|c|c|c|c|c|c|c|c|}
\hline Species & Group & B (22) & $\mathrm{C}(24)$ & $\mathrm{D}(7)$ & E (13) & $\begin{array}{l}\text { One-way } \\
\text { ANOVA }\end{array}$ & \multicolumn{5}{|c|}{ Tukey-Kramer test } \\
\hline \multicolumn{12}{|l|}{ Centric diatoms } \\
\hline Chaetoceros affinis & 475.7 & 458.2 & 45.0 & 0 & 0 & NS & & & & & \\
\hline Chaetoceros borealis & 77.1 & 32.7 & 22.5 & 0 & 96.9 & NS & & & & & \\
\hline Chaetoceros compressus & 77.1 & 343.6 & 457.5 & 0 & 0 & NS & & & & & \\
\hline Chaetoceros concavicornis & 154.3 & 286.4 & 90.0 & 51.4 & 207.7 & NS & & & & & \\
\hline Chaetoceros convolutus & 257.1 & 523.6 & 817.5 & 514.3 & 484.6 & NS & & & & & \\
\hline Chaetoceros decipience & 38.6 & 81.8 & 112.5 & 0 & 0 & NS & & & & & \\
\hline Chaetoceros furcellatus (resting spore) & 205.7 & 32.7 & 142.5 & 77.1 & 138.5 & NS & & & & & \\
\hline Chaetoceros laciniosus & 25.7 & 90.0 & 120.0 & 0 & 0 & NS & & & & & \\
\hline Chaetoceros sp. & 257.1 & 8.2 & 60.0 & 102.9 & 0 & $*$ & & $\underline{B}$ & $\mathrm{C}$ & $\mathrm{D}$ & A \\
\hline Dactyliosolen fragilissimus & 192.9 & 98.2 & 0 & 0 & 0 & NS & & & & & \\
\hline Leptocylindrus danicus & 90.0 & 2593.6 & 4590.0 & 25.7 & 69.2 & $* * *$ & $\mathrm{D}$ & E & $\mathrm{A}$ & $\underline{B}$ & $\underline{\mathrm{C}}$ \\
\hline Leptocylindrus danicus (resting spore) & 192.9 & 0 & 52.5 & 0 & 0 & NS & & & & & \\
\hline Leptocylindrus minimus & 90.0 & 310.9 & 585.0 & 77.1 & 0 & $* *$ & E & $\mathrm{D}$ & A & B & $\mathrm{C}$ \\
\hline Proboscia alata & 64.3 & 310.9 & 1050.0 & 51.4 & 193.8 & $* * *$ & $\mathrm{D}$ & $\mathrm{A}$ & $\mathrm{E}$ & $\mathrm{B}$ & $\underline{\mathrm{C}}$ \\
\hline Rhizosolenia borealis & 12.9 & 8.2 & 30.0 & 25.7 & 13.8 & NS & & & & & \\
\hline Rhizosolenia setigera & 205.7 & 90.0 & 180.0 & 102.9 & 152.3 & NS & & & & & \\
\hline Rhizosolenia spp. & 12.9 & 8.2 & 7.5 & 0 & 13.8 & NS & & & & & \\
\hline \multicolumn{12}{|l|}{ Pennate diatoms } \\
\hline Cylindrotheca closterium & 205.7 & 1178.2 & 3060.0 & 411.4 & 2713.8 & $* * *$ & A & $\mathrm{D}$ & $\mathrm{B}$ & $\mathrm{E}$ & $\mathrm{C}$ \\
\hline Navicula spp. & 0 & 16.4 & 7.5 & 0 & 0 & NS & & & & & \\
\hline \multicolumn{12}{|l|}{ Thecate dinoflagellates } \\
\hline Alexandrium tamarense & 38.6 & 110.5 & 131.3 & 25.7 & 173.1 & NS & & & & & \\
\hline Ceratium horridum & 0 & 0 & 0 & 0 & 6.9 & NS & & & & & \\
\hline Gonyaulax scrippsae & 6.4 & 4.1 & 3.8 & 0 & 6.9 & NS & & & & & \\
\hline Gonyaulax spp. & 0 & 12.3 & 0 & 0 & 6.9 & NS & & & & & \\
\hline Oxytoxum sp. 1 & 96.4 & 90.0 & 82.5 & 51.4 & 96.9 & NS & & & & & \\
\hline Oxytoxum sp. 2 & 0 & 4.1 & 7.5 & 0 & 27.7 & NS & & & & & \\
\hline Prorocentrum balticum & 102.9 & 237.3 & 191.3 & 167.1 & 256.2 & NS & & & & & \\
\hline Prorocentrum compressum & 6.4 & 0 & 3.8 & 0 & 0 & NS & & & & & \\
\hline Prorocentrum minimum & 19.3 & 20.5 & 41.3 & 12.9 & 13.8 & NS & & & & & \\
\hline Protoceratium reticulatum & 0 & 69.5 & 30.0 & 12.9 & 27.7 & $*$ & & $\mathrm{D}$ & E & $\mathrm{C}$ & B \\
\hline Protoperidinium avellanum & 45.0 & 98.2 & 105.0 & 12.9 & 76.2 & NS & & & & & \\
\hline Protoperidinium bipes & 12.9 & 130.9 & 168.8 & 0 & 124.6 & $* *$ & & A & $\mathrm{E}$ & B & $\mathrm{C}$ \\
\hline Protoperidinium conicum & 0 & 0 & 11.3 & 0 & 6.9 & NS & & & & & \\
\hline Protoperidinium leonis & 0 & 0 & 3.8 & 0 & 0 & NS & & & & & \\
\hline Protoperidinium marukawai & 0 & 24.5 & 7.5 & 0 & 13.8 & NS & & & & & \\
\hline Protoperidinium mite & 0 & 0 & 3.8 & 0 & 0 & NS & & & & & \\
\hline Protoperidinium monovelum & 19.3 & 61.4 & 33.8 & 0 & 6.9 & NS & & & & & \\
\hline Protoperidinium pellucidum & 0 & 16.4 & 11.3 & 0 & 6.9 & NS & & & & & \\
\hline Protoperidinium punctulatum & 25.7 & 143.2 & 97.5 & 0 & 124.6 & NS & & & & & \\
\hline Protoperidinium subinerme & 0 & 8.2 & 0 & 12.9 & 0 & NS & & & & & \\
\hline Protoperidinium thorianum & 12.9 & 106.4 & 82.5 & 51.4 & 103.8 & NS & & & & & \\
\hline Protoperidinium sp. 1 & 0 & 4.1 & 3.8 & 0 & 0 & NS & & & & & \\
\hline Protoperidinium spp. & 0 & 4.1 & 0 & 0 & 6.9 & NS & & & & & \\
\hline Scripsiella crystallina & 6.4 & 57.3 & 60.0 & 0 & 55.4 & NS & & & & & \\
\hline \multicolumn{12}{|l|}{ Athecate dinoflagellates } \\
\hline Gymnodinium spp. & 353.6 & 695.5 & 817.5 & 192.9 & 546.9 & NS & & & & & \\
\hline \multicolumn{12}{|l|}{ Oligotrich ciliates } \\
\hline Lohmanniella spp. & 12.9 & 8.2 & 30.0 & 25.7 & 13.8 & NS & & & & & \\
\hline Strobilidium spp. & 360.0 & 515.5 & 757.5 & 308.6 & 304.6 & NS & & & & & \\
\hline Strombidium strobilum & 0 & 0 & 105.0 & 51.4 & 41.5 & NS & & & & & \\
\hline Strombidium spp. & 720.0 & 736.4 & 1087.5 & 180.0 & 955.4 & NS & & & & & \\
\hline Tontonia gracillima & 64.3 & 49.1 & 135.0 & 0 & 27.7 & NS & & & & & \\
\hline \multicolumn{12}{|l|}{ Tintinnid ciliates } \\
\hline Parafavelladenticulata & 0 & 0 & 7.5 & 0 & 0 & NS & & & & & \\
\hline Ptychocylis obtusa & 12.9 & 16.4 & 30.0 & 0 & 96.9 & $*$ & A & B & $\mathrm{C}$ & E & \\
\hline Tintinnopsis sp. & 12.9 & 0 & 7.5 & 0 & 0 & NS & & & & & \\
\hline
\end{tabular}


were observed to dominate on various occasions. For example, from 19 to 23 September, after the SWE, group C dominated the water column group. After that, group E was found to be dominant on 24 and 25 September. At the greatest depth, $30 \mathrm{~m}$, group A was dominant throughout most of the study period.

\section{Discussion}

\subsection{Characteristics of a microplankton community}

To obtain information on the microplankton community in the Chukchi Sea, geographical changes in community structure during the summer months (Joo et al., 2012; Matsuno et al., 2014; Yang et al., 2015) as well as seasonal and horizontal changes in diatoms (Sukhanova et al., 2009) were recorded. Because the study region and season were comparable to those in Matsuno et al. (2014), we compared the characteristics of the microplankton community in this study. Matsuno et al. (2014) classified the microplankton community into five groups (A to E) based on abundance and concluded that the grouping was strongly correlated with the environmental parameters, which varied by water mass. When comparing the findings of this study with the environmental parameters of Matsuno et al. (2014), ranges of surface salinity (31.0-32.7) and chl $a\left(>1 \mu \mathrm{g} \mathrm{L}^{-1}\right)$ indicated that the microplankton community studied herein corresponds to group B of Matsuno et al. (2014). Matsuno et al.'s (2014) group had characteristics of high abundance (mean 31.0 cells $\mathrm{mL}^{-1}$ ), a predominance of diatoms ( $78 \%$ of mean total microplankton abundance), and the microplankton are found throughout the Chukchi Sea Shelf (Matsuno et al., 2014). In comparison with the Matsuno et al. (2014) results, our study found a slightly lower abundance (range 2.6 to 17.6 cells $\mathrm{mL}^{-1}$ ) and lower diatom composition $(65 \%)$. The variations between the two studies may be related to the current study's late sampling period (10 to 25 September).

In the biomass base, Yang et al. (2015) divided the microplankton community in this region into three groups - the diatom-dominated eutrophic Chukchi Sea Shelf, the picoplankton-dominated oligotrophic Northwind Abyssal Plain and the picoplankton- and diatom-dominated Northwind Ridge. Comparing the classifications, the diatomdominated microplankton community of this study may correspond to Yang et al.'s (2015) Chukchi Sea Shelf group. The dominant species of this study - the pennate diatom $C$. closterium, the thecate dinoflagellate $P$. balticum, the athecate dinoflagellate Gymnodinium spp. and the oligotrich Strombidium spp. - are all species that have been listed as important and that are characterized in Matsuno et al.'s (2014) groups.

With respect to seasonal changes, diatoms $(>5 \mu \mathrm{m})$ and haptophytes dominated during the spring months, while small prasinophytes, larger haptophytes and diatoms dominated beneath the nitrate-depleted surface layer during the summer months (Hill et al., 2005). As important species during the summer, Chaetoceros spp., Thalassiosira spp., Fragilaria sp. and Fragilariopsis sp. were reported to dominate at the chl $a$ maximum layer (Booth and Horner, 1997; Coupel et al., 2012). In the autumn months, prasinophytes, which adapt to low temperatures, short daylight hours and an oligotrophic environment, were found to dominate (Lovejoy et al., 2007). At the ice-free surface layer without light limitations, due to the nutrient depletion at the surface layer, phytoplankton, mainly diatoms, are known to exist in the subsurface layer at a maximum depth of 20-30 m (Cota et al., 1996; Hill and Cota, 2005; Sukhanova et al., 2009; Joo et al., 2012). In the present study, nutrient (DIN and silicate) depletion and the occurrence of the sporadic subsurface chl $a$ maximum corresponded well to the aforementioned studies

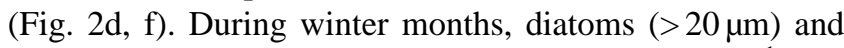
pigmented dinoflagellates were less than $1 \mathrm{cell} \mathrm{mL}^{-1}$ and ciliates (mostly oligotrich) ranged from 0.1 to 2 cells $\mathrm{mL}^{-1}$ (Sherr et al., 2003).

Compared with these seasonal patterns, the subsurface chl $a$ maximum in the present study corresponded to the characteristics from summer to autumn, while the low abundance and dominant species of dinoflagellates and ciliates are similar to the characteristics exhibited during the winter. Given the occurrence of resting spores of diatoms, as referenced in this study (Table 1), the seasonal succession of the microplankton species and community from summer to winter began during the study period.

\subsection{Short-term changes in the microplankton community}

The hydrographic condition of the Arctic Ocean means that low salinity occurs at the surface layer due to the melting of sea ice during the summer months, while high salinity is the result of brine, which occurs during the formation of sea ice during winter months (Macdonald et al., 2002; Nishino et al., 2011). Throughout the study period, sea surface temperatures decreased while salinity gradually increased (Fig. 2). These environmental changes may result from the following processes - atmospheric cooling during autumn induces high-density sea surface water and weakens the density of the pycnocline layer, which then promotes the mixing of the cold and the saline deep water. From 10 to 14 September, less saline ice-melt water was found in the surface layer, the pycnocline layer formed at approximately $25 \mathrm{~m}$, and nutrientrich and saline Pacific summer water was found beneath the ice-melt water (Fig. 2c) (Nishino et al., 2015). It was noted that the SWE, which was observed from 18 to 19 September, temporally weakened the pycnocline layer, thus causing vertical mixing to occur, which then resulted in the supply of rich nutrients to the surface layer (Nishino et al., 2015).

A schematic diagram of short-term changes in the microplankton community and the dominant species during the study (10 to 25 September) is presented in Fig. 7. Based on 
the dominant species and community structure during the study period, the microplankton community was classified into five phases, each of which occurred at 2- to 5-day intervals. Thus, from 10 to 14 September, the abundance of most species as well as the levels of chl $a$ were low, possibly due to the warm, low-saline ice-melt water (phase 1). On 15 and 16 September, the abundance of the centric diatoms $C$. convolutes and L. danicus increased (phase 2). This sudden increase in diatom abundance in phase 2 , which exceeded the range reported for diatom growth $\left(0.35-0.4 \mathrm{day}^{-1}\right)$ in this region (Strom and Fredrickson, 2008; Sherr et al., 2009), could not be explained by cell division growth within the same water masses. Accordingly, as an alternative cause, Nishino et al. (2015) reported that the displacement of the ice-melt seawater during this period caused the horizontal movement of water masses, which, in turn, may have led to the sudden increase in diatoms during this phase.

On 17 and 18 September, diatom abundance decreased, while there was an increase in the thecate dinoflagellate $A$. tamarense, $P$. balticum, Protoperidinium spp., the athecate dinoflagellate Gymnodinium spp., and the oligotrich ciliates Strobilidium spp. and Strombidium spp. (Fig. 7). Within these species, the heterotrophic Gymnodinium spp. and Protoperidinium spp. are known to prey on diatoms and, thus, strongly regulate the phytoplankton community (Olson and Strom, 2002). Therefore, these increases in microzooplankton and the decrease in diatoms may be caused by microzooplankton grazing on diatoms.

In phase 3, 18 and 19 September, the SWE occurred (Nishino et al., 2015). Effects of the SWE included a decrease in temperature and an increase in salinity and chl $a$ (Fig. 7). The dominant microplankton group also changed to group $\mathrm{C}$, which was characterized by the high abundance of the majority of the species (Fig. 6b). Interestingly, chl $a$ almost doubled from phase 2 to 3 , while the abundance of diatoms (primary autotrophic taxa) increased only slightly during this phase. According to Onodera and Nishino (2014), the discrepancy between chl $a$ and diatom abundance may be caused by the time lag in the physiological response of diatoms to the supply of nutrients. That is, diatoms may first use added nutrients from the increase in chl $a$ pigment within the cell and then perform cell division, which is delayed due to the increase in chl $a$, within 3 to 4 days (Fig. 7). An additional characteristic of phase 3 was the remarkable and substantial increase in the abundance of oligotrich ciliates Strobilidium spp. and Strombidium spp. It is well known that the growth rate of heterotrophic microprotists varies with taxa. For example, the oligotrich ciliates grow faster than do the dinoflagellates (Hansen and Jensen, 2000). Thus, the oligotrich ciliates may respond more quickly than the dinoflagellates to an increase in autotrophs, an event that enhances the supply of nutrients caused by the SWE.

From 22 to 23 September, most of the microplankton species increased in abundance and formed a small bloom (phase 4). As a characteristic of this small bloom, the abun-

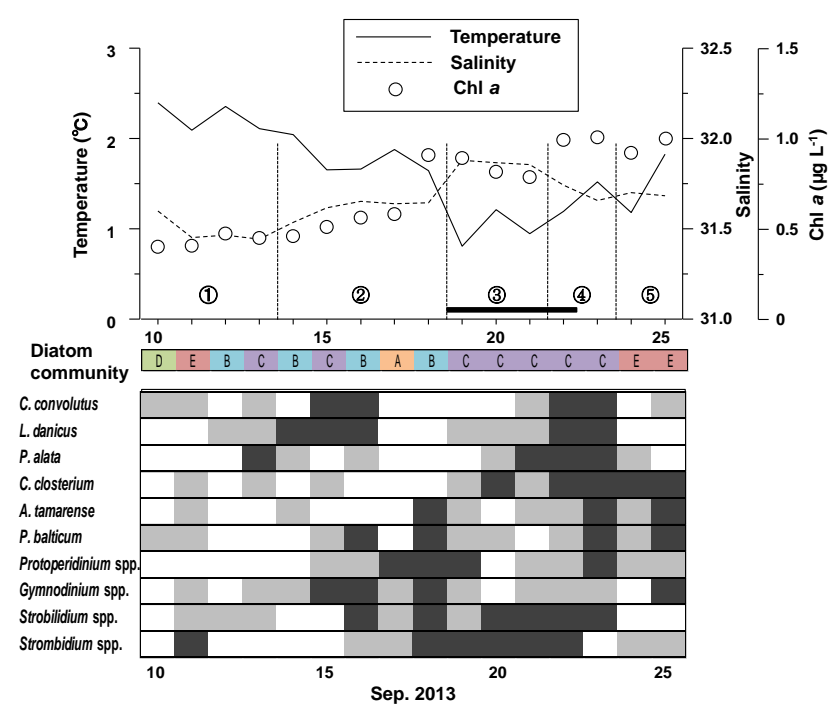

Figure 7. Schematic diagram of temporal changes in environmental parameters (upper panel), diatom community (middle bar) and abundance of dominant microplanktonic species (lower panel) at a water column of a single station in the Chukchi Sea from 10 to 25 September 2013. Values of the upper panel indicate integrated mean data. The solid bar indicates the timing of a strong wind event. Black, grey and white in the lower panel indicate relative abundance - high, middle and low, respectively - of each species in a 0 to $30 \mathrm{~m}$ column of water. Based on a dominant community and species, temporal changes in a microprotist community were divided into five phases, which are indicated by the circled numbers (1 to 5) and dashed lines in the upper panel. For details, see text.

dance of the pennate diatom $C$. closterium increased dramatically. While pennate diatoms were very low in abundance before the SWE, they increased significantly after the SWE (Fig. 3c, Table 1). This increase in pennate diatoms may imply that they respond to the supply of nutrients from the deeper layer through the pycnocline layer after the SWE (Alcoverro et al., 2000).

From 24 to 25 September, the dominant microplankton group shifted to group $\mathrm{E}$, which is characterized by a high abundance of $C$. closterium, a diatom frequently observed in sea ice (Booth and Horner, 1997). Because of the nutrient depletion after the bloom, centric diatoms such as L.danicus may have formed resting spores (Davis et al., 1980) and sunk, thus causing the shift in dominant taxa from centric diatoms to pennate diatoms by the end of this study (phase 5). The microplankton community in the upper layer ( 0 to $20 \mathrm{~m}$ ) demonstrated clear temporal changes within a 2- to 5-day interval. In contrast to the shallower layer, the microplankton community at the deepest sampling depth $(30 \mathrm{~m})$ was composed of groups $\mathrm{A}$ and $\mathrm{D}$, both of which were characterized by low abundance throughout the study period (Fig. 6c). Because the pycnocline layer was observed at approximately $25 \mathrm{~m}$ (Fig. 2a-c), these two groups may form in that layer. 
Throughout this study, it was revealed that atmospheric turbulence, such as SWE, may supply sufficient nutrients to the surface layer, which subsequently enhances a small bloom under the weak stratification of the Chukchi Sea Shelf during the autumn months. After the bloom, the dominant diatom community shifts from centric diatoms to pennate diatoms, thus suggesting that a SWE accelerates the seasonal succession of the microplankton community from summer to winter. Such a SWE-enhanced small bloom in autumn may be fed upon by copepods (Calanus glacialis) immediately (Matsuno et al., 2015). Thus, Matsuno et al. (2015) suggested that the temporal phytoplankton bloom caused by the atmospheric turbulence (SWE) during autumn may have had a positive indirect effect on the mesozooplankton (SWE $\rightarrow$ nutrient supply from the deep layer $\rightarrow$ small phytoplankton bloom $\rightarrow$ copepod feeding) within a short period.

Author contributions. S. Nishino, J. Inoue and T. Kikuchi designed and coordinated this research project. S. Nishino and J. Inoue were chief scientists during the MR13-06 cruise of RV Mirai. K. Matsuno collected the water samples during the cruise. N. Yokoi conducted species identification and the enumeration of the microplankton samples in the land laboratory. M. Ichinomiya and J. Onodera gave valuable comments to analyse the microplankton community. $\mathrm{N}$. Yokoi and A. Yamaguchi wrote the manuscript with contributions from all co-authors.

Acknowledgements. We are grateful to the captain, officers and crew of the RV Mirai (JAMSTEC), operated by GODI, for their help with the sample collection. This study was supported by the Green Network of Excellence Program's (GRENE Program) Arctic Climate Change Research Project: "Rapid Change of the Arctic Climate System and its Global Influences". This study was partially supported by a Grant-in-Aid for Scientific Research (A) (24248032) and a Grant-in-Aid for Scientific Research on Innovative Areas (24110005) from the JSPS.

Edited by: J. Grebmeier

\section{References}

Alcoverro, T., Conte, E., and Mazzella, L.: Production of mucilage by the Adriatic epipelic diatom Cylindrotheca closterium (Bacillariophyceae) under nutrient limitation, J. Phycol., 36, 10871095, doi:10.1046/j.1529-8817.2000.99193.x, 2000.

Booth, B. C. and Horner, R. A.: Microalgae on the Arctic Ocean section, 1994: Species abundance and biomass, Deep-Sea Res. Pt. II, 44, 1607-1622, doi:10.1016/S0967-0645(97)00057-X, 1997.

Bray, J. R and Curtis, J. T.: An ordination of the upland forest communities of southern Wisconsin, Ecol. Monogr., 27, 325-349, 1957.

Cota, G. F., Pomeroy, L. R., Harrison, W. G., Jones, E. P., Peters, F., Sheldon, W. J., and Weingartner, T. R.: Nutrients, primary production and microbial heterotrophy in the southeastern Chukchi
Sea: Arctic summer nutrient depletion and heterotrophy, Mar. Ecol.-Prog. Ser., 135, 247-258, doi:10.3354/meps135247, 1996. Coupel, P., Jin, H. Y., Joo, M., Horner, R., Bouvet, H. A., Sicre, M.-A., Gascard, J.-C., Chen, J. F., Garçon, V., and RuizPino, D.: Phytoplankton distribution in unusually low sea ice cover over the Pacific Arctic, Biogeosciences, 9, 4835-4850, doi:10.5194/bg-9-4835-2012, 2012.

Davis, C. O., Hollibaugh, J. T., Seibert, D. L., Thomas, W. H., and Harrison, P. J.: Formation of resting spores by Leptocylindrus danicus (Bacillariophyceae) in a controlled experimental ecosystem, J. Phycol., 16, 296-302, doi:10.1111/j.15298817.1980.tb03034.x, 1980.

Field, J. G., Clarke, K. R., and Warwick, R. M.: A practical strategy for analyzing multispecies distribution patterns, Mar. Ecol.-Prog. Ser., 8, 37-52, doi:10.3354/meps008037, 1982.

Fritz, L. and Triemer, R. E.: A rapid simple technique utilizing Calcofluor white M2R for the visualization of dinoflagellate thecal plates, J. Phycol., 21, 662-664, doi:10.1111/j.00223646.1985.00662.x, 1985.

Fukuyo, Y., Inoue, H., and Takayama, H.: Class Dinophyceae, In: An illustrated guide to marine plankton in Japan, edited by: Chihara, M. and Murano, M., Tokai University Press, Tokyo, Japan, 31-112, 1997.

Hansen, B. W. and Jensen, F.: Specific growth rates of protozooplankton in the marginal ice zone of the central Barents Sea during spring, J. Mar. Biol. Assoc. UK, 80, 37-44, doi:10.1017/S002531549900154X, 2000.

Hasle, G. R. and Syvertsen, E. E.: Marine diatoms, In: Identifying marine phytoplankton, edited by: Tomas, C. R., Academic Press, San Diego, USA, 5-385, 1997.

Hill, V. and Cota, G.: Spatial patterns of primary production on the shelf, slope and basin of the western Arctic in 2002, DeepSea Res. Pt. II, 52, 3344-3354, doi:10.1016/j.dsr2.2005.10.001, 2005.

Hill, V., Cota, G., and Stockwell, D.: Spring and summer phytoplankton communities in the Chukchi and eastern Beaufort Seas, Deep-Sea Res. Pt. II, 52, 3369-3385, doi:10.1016/j.dsr2.2005.10.010, 2005.

Hoppenrath, M., Elbrächter, M., and Drebes, G.: Marine phytoplankton, E. Schweizerbart'sche Verlagsbuchhandlung, Stuttgart, Germany, 264 pp., 2009.

Joo, H. M., Lee, S. H., Jung, S. W., Dahms, H., and Lee, J. H.: Latitudinal variation of phytoplankton communities in the western Arctic Ocean, Deep-Sea Res. Pt. II, 81-84, 3-17, doi:10.1016/j.dsr2.2011.06.004, 2012.

Kawaguchi, Y., Nishono, S., and Inoue, J.: Fixed-point observation of mixed layer evolution in the seasonally ice-free Chukchi Sea: turbulent mixing due to gale winds and gravity waves, J. Phys. Oceanogr., 45, 836-853, doi:10.1175/JPO-D-14-0149.1, 2015.

Lovejoy, C., Legendre, L., Martineau, M. J., Bâcle, J., and von Quillfeldt, C. H.: Distribution, phylogeny, and growth of coldadapted picoprasinophytes in Arctic Seas, J. Phycol., 43, 78-89, doi:10.1111/j.1529-8817.2006.00310.x, 2007.

Macdonald, R. W., McLaughlin, F. A., and Carmack, E. C.: Fresh water and its sources during the SHEBA drift in the Canada Basin of the Arctic Ocean, Deep-Sea Res. Pt. I, 49, 1769-1785, doi:10.1016/S0967-0637(02)00097-3, 2002. 
Maeda, M.: Suborder Oligotrichida, In: An illustrated guide to marine plankton in Japan, edited by: Chihara, M. and Murano, M., Tokyo University Press, Tokyo, Japan, 397-420, 1997.

Matsuno, K., Ichinomiya, M., Yamaguchi, A., Imai, I., and Kikuchi, T.: Horizontal distribution of microprotist community structure in the western Arctic Ocean during late summer and early fall of 2010, Polar Biol., 37, 1185-1195, doi:10.1007/s00300-0141512-z, 2014.

Matsuno, K., Yamaguchi, A., Nishino, S., Inoue, J., and Kikuchi, T.: Short-term changes in the mesozooplankton community and copepod gut pigment in the Chukchi Sea in autumn: reflections of a strong wind event, Biogeosciences, 12, 4005-4015, doi:10.5194/bg-12-4005-2015, 2015.

McCabe, G. J., Clark, M. P., and Serreze, M. C.: Trends in northern hemisphere surface cyclone frequency and intensity, J. Clim., 14, 2763-2768, doi:10.1175/15200442(2001)014<2763:TINHSC>2.0.CO;2, 2001.

Nishino, S., Itoh, M., Kawaguchi, Y., Kikuchi, T., and Aoyama, M.: Impact of an unusually large warm-core eddy on distributions of nutrients and phytoplankton in the southwestern Canada Basin during late summer/early fall 2010, Geophys. Res. Lett., 38, L16602, doi:10.1029/2011GL047885, 2011.

Nishino, S., Kawaguchi, Y., Inoue, J., Hirawake, T., Fujiwara, A., Futsuki, R., Onodera, J., and Aoyama, M.: Nutrient supply and biological response to wind-induced mixing, intertial motion, and currents in the northern Chukchi Sea, J. Geophys. Res., 20, 1975-1992, doi:10.1002/2014JC010407, 2015.

Olson, M. B. and Strom, S. L.: Phytoplankton growth, microzooplankton herbivory and community structure in the southeast Bering Sea: Insight into the formation and temporal persistence of an Emiliania huxleyi bloom, Deep-Sea Res. Pt. II, 49, 59695990, doi:10.1016/S0967-0645(02)00329-6, 2002.

Onodera, J. and Nishino, S.: Fixed-point observation of diatom biocoenosis and water mass condition in the Northern Chukchi Sea during September 2013, JpGU Meeting 2014, Yokohama, Japan, Abstract, ACG36-P20, 2014.

Sepp, M. and Jaagus, J.: Changes in the activity and tracks of arctic cyclones, Clim. Change, 105, 577-595, doi:10.1007/s10584010-9893-7, 2011.

Serreze, M. C., Walsh, J. E., Chapin III, F., Osterkamp, T., Dyurgerov, M., Romanovsky, V., and Barry, R. G.: Observational evidence of recent change in the northern high-latitude environment, Clim. Change, 46, 159-207, doi:10.1023/A:1005504031923, 2000.
Sherr, E. and Sherr, B.: Role of microbes in pelagic food webs: A revised concept, Limnol. Oceanogr., 33, 1225-1227, doi:10.4319/lo.1988.33.5.1225, 1988.

Sherr, E. B., Sherr, B. F., and Fessenden, L.: Heterotrophic protists in the central Arctic Ocean, Deep-Sea Res. Pt. II, 44, 1665-1682, doi:10.1016/S0967-0645(97)00050-7, 1997.

Sherr, E. B., Sherr, B. F., Wheeler, P. A., and Thompson, K.: Temporal and spatial variation in stocks of autotrophic and heterotrophic microbes in the upper water column of the central Arctic Ocean, Deep-Sea Res. Pt. I, 50, 557-571, doi:10.1016/S0967-0637(03)00031-1, 2003.

Sherr, E. B., Sherr, B. F., and Hartz, A. J.: Microzooplankton grazing impact in the western Arctic Ocean, Deep-Sea Res. Pt. II, 56, 1264-1273, doi:10.1016/j.dsr2.2008.10.036, 2009.

Steele, M., Ermold, W., and Zhang, J.: Arctic Ocean surface warming trends over the past 100 years, Geophys. Res. Lett., 35, L02614, doi:10.1029/2007GL031651, 2008.

Stroeve, J., Marika, M. H., Walt, M., Ted, S., and Mark, S.: Arctic sea ice decline!: Faster than forecast?, Geophys. Res. Lett., 34, L09501, doi:10.1029/2007GL029703, 2007.

Strom, S. L. and Fredrickson, K. A.: Intense stratification leads to phytoplankton nutrient limitation and reduced microzooplankton grazing in the southeastern Bering Sea, Deep-Sea Res. Pt. II, 55, 1761-1774, doi:10.1016/j.dsr2.2008.04.008, 2008.

Sukhanova, I. N., Flint, M. V., Pautova, L. A., Stockwell, D. A., Grebmeier, J. M., and Sergeeva, V. M.: Phytoplankton of the western Arctic in the spring and summer of 2002: Structure and seasonal changes, Deep-Sea Res. Pt. II, 56, 1223-1236, doi:10.1016/j.dsr2.2008.12.030, 2009.

Taniguchi, A.: Suborder Tintinnina, In: An illustrated guide to marine plankton in Japan, edited by: Chihara, M. and Murano, M. Tokai University Press, Tokyo, Japan, 421-483, 1997.

Yang, E. J., Ha, H. K., and Kang, S.: Microzooplankton community structure and grazing impact on major phytoplankton in the Chukchi Sea and the western Canada Basin, Arctic Ocean, DeepSea Res. Pt. II, 120, 91-102, doi:10.1016/j.dsr2.2014.05.020, 2015. 